\title{
Intrinsic Stability Study and Forced Degradation Profiling of Olopatadine Hydrochloride by RP- HPLC-DAD-HRMS Method
}

\section{RP-YBSK -DAD-HRMS Yöntemi ile Olopatadin Hidrokloridin Gerçek Stabilite ve Zorlanmış Bozunma Profilinin Oluşturulması}

\author{
(D) Pawan Kumar BASNIWAL 1 ,2*, (D) Deepti JAIN1 \\ 1School of Pharmaceutical Sciences, Rajiv Gandhi Technological University, Bhopal, Madhya Pradesh, India \\ 2Lal Bahadur Shastri College of Pharmacy, Jaipur, Rajasthan, India
}

\begin{abstract}
Objectives: Forced degradation determines the intrinsic stability of a molecule by establishing degradation pathways in order to identify the likely degradation products (DPs). The objective of the present research was to establish intrinsic stability and forced degradation profiling of olopatadine hydrochloride.

Materials and Methods: The intrinsic stability of olopatadine hydrochloride was evaluated by RP-HPLC, where a mixture of $0.1 \%$ formic acid and organic phase (methanol:acetonitrile; $50: 50 \% \mathrm{v} / \mathrm{v}$ ) was used as mobile phase at $1.0 \mathrm{~mL} / \mathrm{min}$ in gradient mode. Different stress conditions were employed to explore the intrinsic stability of olopatadine hydrochloride.

Results: In acidic condition, five DPs, i.e. OLO1, OLO2, OLO3, OLO4, and OLO5, were observed. OLO5 was the major DP that increased with time and the peak area of OLO was decreased. In addition to OLO3 and OLO5, two more DPs were observed in alkaline condition, i.e. OLO6 and OLO7. OLO5 and OLO6 were two major DPs; OLO5 increased with time while OLO6 had a zigzag pattern of peak area with time. All DPs of neutral condition were also found in acidic condition while OLO3 and OLO5 were common in all three types of hydrolytic degradation.

Conclusion: Thus, OLO has similar pattern of degradation profiling in all hydrolytic conditions (acidic, alkaline, and neutral). No degradation was found in thermal, ultraviolet light, or oxidative conditions over 10 days. OLO-Imp was recognized as an analogue structure of OLO and proposed as 11-[(3-dimethylamino)-propylidene]-6,11-dihydro-dibenz[b,e]oxepin-2-propanoic acid in standard drug. OLO1 was identified as (2-(4-(dimethylamino) butyl) phenyl)methanol, which may be formed by cleavage of the tricyclic ring in neutral condition.
\end{abstract}

Key words: Olopatadine hydrochloride, forced degradation, HPLC

öz

Amaç: Zorlanmış bozunma, muhtemel bozunma ürünlerini (DP) tanımlamak için bozunma yolları oluşturarak bir molekülün gerçek stabilitesini belirler. Bu araştırmanın amacı, olopatadin hidrokloridin gerçek stabilitesini ve zorlanmış bozunma profilini oluşturmaktır.

Gereç ve Yöntemler: Olopatadin hidrokloridin gerçek stabilitesi, \%0,1 formik asit ve organik faz karışımı (metanol: asetonitril;\% 50:50 h/h) mobil faz olarak 1,0 mL/dak'de gradyan modunda kullanımıyla RP-YBSK ile değerlendirilmiştir. Olopatadin hidrokloridin gerçek stabilitesini araştırmak için farklı stres koşulları kullanılmıştır.

Bulgular: Asidik koşulda, beş DP, yani OL01, OLO2, OLO3, OLO4 ve OLO5 gözlenmiştir. başlıca DP OLO5 idi, pik süresi artmış ve OLO'nun pik alanı azalmıştır. OLO3 ve OLO5'e ek olarak, alkali koşullarda, iki DP daha, OLO6 ve OLO7 gözlenmiştir. OLO5 ve OLO6 iki ana DP idi; OLO5 zamanla

*Correspondence: E-mail: pawanbasniwal@gmail.com, Phone: +9414788171 ORCID: orcid.org/0000-0002-0001-7414

Received: 14.03.2018, Accepted: 23.07.2018

๑Turk J Pharm Sci, Published by Galenos Publishing House. 
artarken OLO6 zamanla zikzak bir tepe alanı düzenine sahipti. Nötral koşullardaki bütün DP'ler asidik koşullarda da bulunurken, OLO3 ve OLO5 üç hidrolitik bozunma tipinde de ortaktı.

Sonuç: OLO, tüm hidrolitik koșullarda (asidik, alkali ve nötr) benzer bir bozulma profiline sahiptir. Termal, ultraviyole ıșığı veya oksidatif koșullarda 10 gün boyunca hiçbir bozulma bulunamamıştır. OLO-Imp, OLO'nun analog bir yapısı olarak kabul edilmiş ve standart ilaçta 11-[(3-dimetilamino) -propiliden]-6,11-dihidro-dibenz [b, e] oksepin-2-propanoik asit olarak önerilmiștir. OLO1, trisiklik halkanın nötr koșulda bölünmesiyle oluşturulabilecek (2-[4-(dimetilamino) butil] fenil) metanol olarak tanımlanmıștır.

Anahtar kelimeler: Olopatadin hidroklorid, zorlanmış bozunma, YBSK

\section{INTRODUCTION}

Forced degradation involves degradation of a new drug substance or drug product at more severe conditions than accelerated conditions. Forced degradation studies afford information for the identification of possible degradants, degradation pathways, and the inherent stability of the active pharmaceutical ingredient. It also yields information about any possible polymorphic or enantiomeric substances and the difference between drug related degradation and excipient interferences. A New Drug Application (NDA) registration requires data of forced degradation studies in the form of forced degradation products (DPs), degradation reaction kinetics, structure, mass balance, drug peak purity, etc. Therefore, forced degradation and impurity profiling is one of the inputs for an NDA registration manuscript. 'Due to the presence of impurities or DPs The Food and Drug Administration has recalled finished pharmaceutical products; they include adagen (pegademase bovine) injection, azelastine hydrochloride ophthalmic solution, brimonidine tartrate ophthalmic solution, ciclopirox gel, diflorasone diacetate cream, fludeoxyglucose F18 injections, hydroxyzine hydrochloride oral solution, leflunomide tablets, pediatric atropine sulfate injection, prednisolone sodium phosphate oral solution, ropinirole hydrochloride tablets, and topiramate tablets. ${ }^{2}$ The intrinsic stability of armodafinil hydrochloride was explored by forced degradation and impurity profiling, where the structures of four DPs were established and a possible pathway was postulated. In the present work, the whole research methodology was adopted from Jain and Basniwal. $^{3}$

Chemically, olopatadine (OLO) is 11-((Z)-3-(dimethyl-amino) propylidene)-6,11-dihydro-dibenz[b,e] oxepin-2-acetic acid ${ }^{4}$ and is indicated for allergic rhinitis, urticaria, and itching resulting from skin diseases such as eczema/dermatitis, prurigo, pruritus cutaneous, psoriasis vulgaris, and multiform exudative erythema. OLO primarily acts as a selective histamine $\mathrm{H} 1$ receptor antagonist. It also inhibits the production and release of chemical mediators such as leukotriene and thromboxane, and the release of the neurotransmitter tachykinin. ${ }^{5-9}$ Analytical methods for OLO determination in different matrices have been reported, i.e. radioimmunoassay, ${ }^{10}$ liquid chromatography (LC) with tandem mass spectrometry,1 LC-ESI-MS-MS,12,13 capillary zone electrophoretic method, ${ }^{14}$ high performance LC (HPLC), and high-performance thin-layer chromatography (HPTLC), ${ }^{15}$ but there is no study reported on forced degradation profiling including the intrinsic stability of OLO. The objective of forced degradation is to provide guidance for the development of executing purposeful degradation experiments for pharmaceutical drug candidates. The International Council for Harmonisation of Technical Requirements for Pharmaceuticals for Human Use (ICH) Guideline provides some guidance on stress testing or purposeful degradation stress testing helps to determine the intrinsic stability of the molecule by establishing degradation pathways in order to identify the likely DPs. ${ }^{16}$ The objective of present research was to establish intrinsic stability and forced degradation profiling of OLO by reverse phase (RP) HPLC diode array detector (DAD) high-resolution mass spectrometry (HRMS).

\section{EXPERIMENTAL}

\section{MATERIALS AND METHODS}

\section{Chemicals and reagent}

Working standard of OLO hydrochloride was gifted by Ranbaxy Laboratories Limited, Gurgaon, Harayana. HPLC grade solvents (methanol and acetonitrile), formic acid, hydrochloric acid, sodium hydroxide, and hydrogen peroxide were procured from Merck Specialties Private Limited, Mumbai, India. Triple distilled water was prepared in-house.

\section{Instrument and chromatography}

All dilutions, mobile phase, and other solutions were filtered through a 0.2- $\mu \mathrm{m}$ nylon filter and chromatographed by an Agilent Infinity 1260 series system equipped with a 1260 binary pump VL 400 bar, 1260 manual injector 600 bar, Rheodyne 7725i 7-port sample injection valve with $20 \mu \mathrm{L}$ fixed loop, ZORBAX Eclipse Plus C18 (250×4.6 mm, $5 \mu \mathrm{m}), 1260$ DAD VL, $20 \mathrm{~Hz}$ detector, standard flow cell $10 \mathrm{~mm}, 13 \mu \mathrm{L}, 120$ bar, OpenLab CDS EZChrom Ed. Workstation, and syringe $50.0 \mu \mathrm{L}, \mathrm{FN}, \mathrm{LC}$ tip. Micromass Q-TOF micro (Waters) LC-mass spectrometry (MS) was performed in HRMS mode using electrospray positive ionization. The parameters desolvation gas ( $500 \mathrm{~L} / \mathrm{h})$, cone gas $(25 \mathrm{~L} / \mathrm{h})$, desolvation temperature $\left(250^{\circ} \mathrm{C}\right)$, source temperature $\left(120^{\circ} \mathrm{C}\right)$, capillary voltage $(3000 \mathrm{~V})$, cone voltage $(30 \mathrm{~V})$, and collision energy $(10 \mathrm{~V})$ were used for HRMS analysis. All dilutions, mobile phase, and other solutions used for the analysis were filtered through a 0.2- $\mu \mathrm{m}$ nylon filter (Ultipor ${ }^{\circledR}$ N66 Nylon 6,6 membrane, Pall Sciences, Pall India Pvt. Ltd. Mumbai, India). The mobile phase was composed of water adjusted to $0.1 \%$ formic acid $(A)$ and acetonitrile and methanol (50:50) (B) in gradient mode (Tmin/A:B; T0/70:30; T4/70:30; T14/20:80; T22/80:20; T25/70:30). The flow rate was set to $1.0 \mathrm{~mL} / \mathrm{min}$ with UV detector wavelength fixed at $300 \mathrm{~nm}$. The injection volume was $20 \mu \mathrm{L}$. 


\section{Standard solution}

An accurately weighed amount of $100 \mathrm{mg}$ of OLO was dissolved in $100 \mathrm{~mL}$ of methanol to prepare stock $P(1000 \mu \mathrm{g} / \mathrm{mL})$. An aliquot of stock $P$ was diluted to prepare stock $Q(100 \mu \mathrm{g} / \mathrm{mL})$, which was used to prepare a series of standard dilutions, i.e. 2, $4,6,8$, and $10 \mu \mathrm{g} / \mathrm{mL}$ OLO.

\section{Method validation}

As per $\mathrm{ICH}$ guidelines, ${ }^{17-19}$ the proposed method was validated for the stability indicating assay and to establish the inherent stability of OLO drug with forced degradation profiling in different conditions by RP-HPLC determination. The developed method was validated to assure the reliability of results of analysis for different parameters, i.e. linearity, range, accuracy, precision, robustness, limit of quantification (LOQ), limit of detection (LOD), and specificity. The serial dilutions $(2-10 \mu \mathrm{g} / \mathrm{mL})$ of the OLO in 50\% methanol in triplicate were used for the linearity determination. Accuracy was determined by recovery method by spiking the standard solution into pre-analyzed samples. The precision of the method was studied under the head of repeatability and intermediate precision. The six replicates of $10 \mu \mathrm{g} / \mathrm{mL}$ were chromatographed subsequently to assure repeatability. The intermediate precision was determined by day-to-day analysis variation and analyst-to-analyst variation in the linearity range. The robustness of the method was studied with variation in the temperature $\left(20,25\right.$, and $30^{\circ} \mathrm{C}$ ) and content of formic acid $(0.1 \%)$ in aqueous phase variation by $5 \%$ change. $L O D$ and $L O Q$ were determined by signal-tonoise ratio. The specificity was ascertained by degrading the drug sample in stressed conditions. Sample solution stability was demonstrated by analyzing six replicates of $10 \mu \mathrm{g} / \mathrm{mL}$ OLO standard samples at different time intervals with freshly prepared mobile phase each time.

\section{Forced degradation}

Forced degradation studies of bulk drug included appropriate solid state (thermal and photolytic) and solution state stress conditions (hydrolytic and oxidative). The stock solution was used for the forced degradation study to provide an indication of the stability indicating the property and specificity of the proposed method. Accurately weighed about $100 \mathrm{mg}$ of OLO was dissolved in $50 \mathrm{~mL}$ of methanol and the volume was made up to $100 \mathrm{~mL}$ with water/0.2 N HCl/0.2 N NaOH to perform hydrolytic degradation in neutral (water), acidic $(0.1 \mathrm{~N} \mathrm{HCl})$, and alkali $(0.1 \mathrm{~N} \mathrm{NaOH})$ conditions, respectively, followed by refluxing at $60^{\circ} \mathrm{C}$. Bulk drug (powder form) was exposed to $60^{\circ} \mathrm{C}$ (hot air oven) and ultraviolet (UV) light separately for temperature and UV degradation, respectively. Oxidative degradation of OLO was performed in $3 \%$ and $10 \% \mathrm{H}_{2} \mathrm{O}_{2}$ solution. Prior to injection, samples were withdrawn at the appropriate time, neutralized (in the case of acid and alkali hydrolysis), and the solutions were diluted with $50 \%$ methanol. Thermal and photolytic degraded drug (solid powder) was dissolved in 50\% methanol to prepare samples for injection.

\section{RESULTS AND DISCUSSION}

\section{Optimization of chromatographic conditions}

OLO was eluted at 3.77 min by the mixture of $0.1 \%$ formic acid and methanol (35:65) on a ZORBAX Eclipse Plus C18 column $(250 \times 4.6 \mathrm{~mm}, 5 \mu \mathrm{m})$ at $1.0 \mathrm{~mL} / \mathrm{min}$ flow rate and it was successfully applied for determination of the OLO drug in dosage form, ${ }^{20}$ but it was not suitable for separation of the DPs along with OLO.

Thus, chromatographic conditions were optimized to develop a stability-indicating assay to separate the related compounds and DPs from the drug content. RP-HPLC mode chromatography was selected based on the solubility and pKa value of OLO. A ZORBAX Eclipse Plus C18 column ( $250 \times 4.6 \mathrm{~mm}, 5 \mu \mathrm{m})$ was used to separate all degradants along with the drug. The wavelength of $300 \mathrm{~nm}$ was selected due to maximum absorbance of all the DP and drug, which was optimized by 1260 DAD VL, $20 \mathrm{~Hz}$ detector.

Peak broadening and splitting were observed with both mobile phases, methanol and water (50:50) and acetonitrile and water (50:50). The drug's peak was merged with the diluent's as the organic phase was increased. After using the acidic aqueous phase (pKa of drug 4.29), the broadening and tailing of the OLO peak persisted. It was improved by increasing the organic phase (methanol) up to $65 \%$. Further, methanol content was reduced to $60 \%$ to resolve $4-5$ grouped peaks in degraded samples, where little separation was found, but the peak shapes were not acceptable. Then acetonitrile content was incorporated in the organic phase along with methanol (50:50). All peaks of degraded samples were very sharp but not well resolved with $0.1 \%$ formic acid and above organic phase (40:60). Degradant peaks were well separated up to 6 min when this ratio was reversed (60:40), but high tailing was observed in the drug's peak. Thus, degradants were well resolved in 60:40 ratios while the drug eluted in 40:60; then it was concluded to run gradient mode.

DPs were resolved before the drug peak but a few of them were merged with the drug peak between 11 and $13 \mathrm{~min}$ and two DPs were merged with each other at $16.5 \mathrm{~min}$ in gradient mode (Tmin/A:B; TO/70:30; T7/70:30; T9/30:70; T17/70:30; T20/70:30). Basically, the above elution mode is not purely gradient; it was a combination of more isocratic and less gradient mode. Fine resolution was observed up to $16 \mathrm{~min}$, when gradient mode was increased (Tmin/A:B; TO/70:30; T5/70:30; T16/30:70; T17/70:30; T20/70:30), but groups of DPs were observed between 16 and $19 \mathrm{~min}$. Therefore, the run time was extended to $25 \mathrm{~min}$ with increased gradient mode (Tmin/ A:B; TO/70:30; T4/70:30; T20/30:70; T22/70:30; T25/70:30). Most of the DPs were resolved but tailing in the drug peak was seen, which may have been due to less exposure to the organic phase, and so it was decided to increase organic content in the mobile phase (Tmin/A:B; TO/70:30; T4/70:30; T14/20:80; T22/70:30; T25/70:30). In this gradient mode, OLO and all DPs in different forced degradation conditions were well separated with acceptable resolution. 


\section{Method validation}

The consistence performance of the HPLC system was assured by system suitability parameters. Six replicates of OLO samples were injected, and column performance parameters like tailing factors, retention time, and number of theoretical plates were observed. The values of \% relative standard deviation (RSD) for these parameters were within the acceptance criteria of system performance. OLO has better separation in the set of conditions as the higher theoretical plates (59526) with less than one unit of \% RSD (0.88). The tailing factor was 0.68 with acceptable \% RSD. The capacity factor was 15.02 , i.e. OLO has sufficient opportunity to interact with the stationary phase, resulting in differential migrations. The co-elution of impurities or degradants is generally investigated by examining peak purity using a PDA detector. The three-dimensional view of the chromatogram confirmed that there was no peak around the OLO elution time. Here the peak purity at 11.62 min was 1.0; there was no interference with elution of OLO at retention time, or nothing was co-eluting along with OLO at $11.62 \mathrm{~min}$. Thus, all system suitability parameters were within the acceptance criteria.

The linear regression equation was $Y=16751 x+26.50$ with correlation coefficient $r^{2}=0.999$ and a calibration graph was plotted for concentration versus area found in the chromatogram. The accuracy of the developed method was assured at all levels of linearity. It was $99.50-100.28 \%$ by the recovery method with \% RSD of 0.32 , which shows the reliability for accuracy of the developed RP-HPLC method. The developed method was performed under two heads: repeatability and intermediate precision. The repeatability of sample injections was measured as the determined amount of OLO in six different serial replicates, which was expressed as $99.89 \%$ with $\%$ RSD of 0.08 , while intermediate precision was evaluated on the heads of interday analysis as well as analyst-to-analyst. Both parameters were determined near to $100 \%(99.93 \%$ and $99.95 \%$ ) with less than unit \% RSD (0.11 and 0.12) at all three levels of concentration.

The robustness of the developed method was assured by the variation in the amount of formic acid (0.1\%) in the aqueous phase of mobile phase composition and temperature of real-time analysis. The three variations in formic acid in the aqueous phase $(0.105 \%, 0.100 \%$, and $0.095 \%)$ and temperature variation $\left(20,25\right.$, and $30^{\circ} \mathrm{C}$ ) had no significant effect of change in parameters on the results. These were found to be 99.97 and 100.17, with \% RSD 0.13 and 0.29 , respectively. The LOD and LOQ were determined by signal-to-noise ratio. These were found to be $0.045 \mu \mathrm{g} / \mathrm{mL}$ and $0.149 \mu \mathrm{g} / \mathrm{mL}$, respectively, which show the sensitivity of the developed method. The \% RSD value was less than two. Analysis of degraded drug sample in stressed conditions was evidence for specificity of the method. The retention time, peak symmetry, peak purity, and UV spectrum of the recorded chromatograms of different samples were confirmed to assure the specificity. The AUC of the OLO peak in the chromatogram decreased with an increase in the AUC of the degradant's peak. This experimental evidence confirmed that the developed method was specific for the analysis of OLO. The stability of OLO was assured during analysis by response ratio. The response ratio of the drug at all concentration level varied between 16565.67 and 16973.33 with \% RSD of 0.89 . This is evidence that the drug is stable in selected solution at room temperature and the RP-HPLC method is continuously sensitive toward the analyte.

\section{Forced degradation profiling}

Acidic degradation: Five DPs, i.e. OLO1 (5.17), OLO2 (7.87), OLO3 (11.11), OLO4 (12.65), and OLO5 (12.91), were observed in acidic condition (Figure 1). OLO5 was the major DP that increased with time and the peak area of OLO was decreased. All DPs appeared on the first day except OLO1 and OLO2, which appeared on fourth and second day, respectively. The peak area of OLO3 and OLO4 increased first and then decreased. The other two DPS, OLO1 and OLO2, increased with time.

Alkaline degradation: OLO was gradually degraded into four DPs, i.e. OLO3 (11.11), OLO6 (12.07), OLO5 (12.91), and OLO7 (17.48), in alkaline condition (Figure 2). OLO3 and OLO5 were common DPs in acidic and alkaline conditions, while OLO6 and OLO7 were newer DPs in basic degradation. OLO5 and OLO6 were two major DPs; OLO5 increased with time while OLO6 had a zigzag pattern of peak area with time. Concentrations of both OLO3 and OLO7 increased with time.

Neutral degradation: All DPs in neutral condition were also found in acidic condition, while OLO3 and OLO5 were common in all three types of hydrolytic degradation (Figure 3). OLO5 was the major DP in all conditions. OLO was gradually degraded and the peak area of all DPs increased with time in neutral condition.

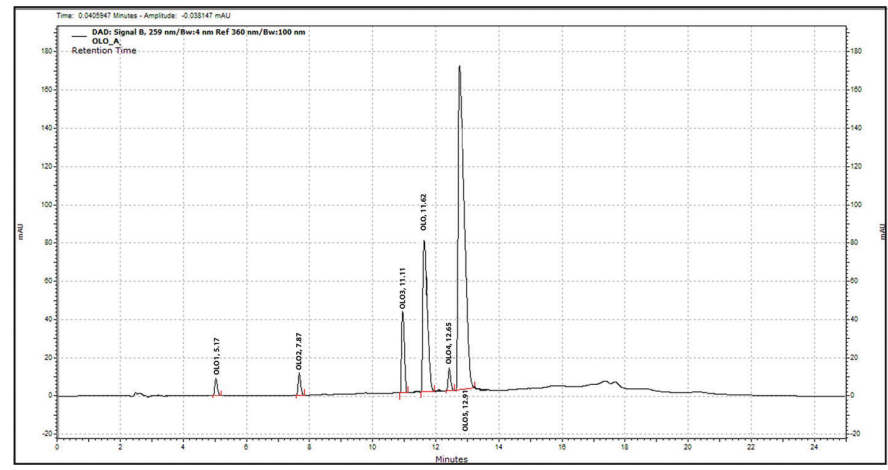

Figure 1. Representative chromatogram of OLO in acidic condition OLO: Olopatadine

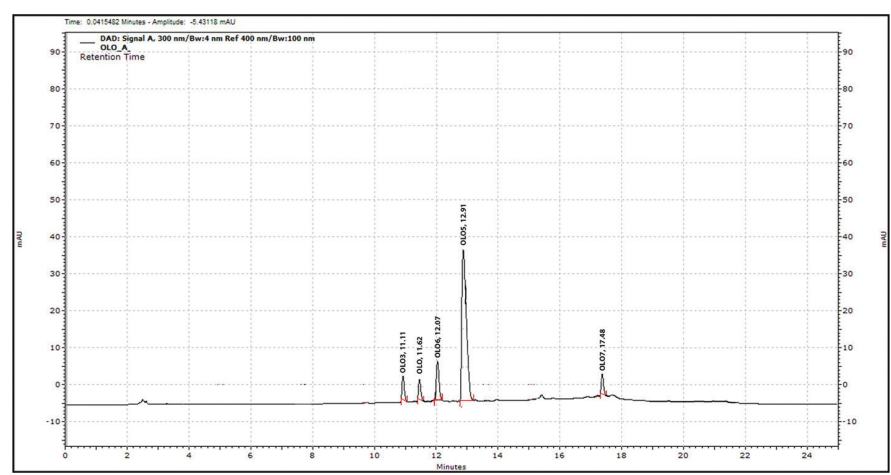

Figure 2. Representative chromatogram of OLO in alkaline condition OLO: Olopatadine 
RP-HPLC analysis of stressed samples of OLO in thermal, oxidative, and photolytic degradation showed that there was no degradation in these conditions. It might be possible that due to solid sample in thermal stress condition no degradation was observed.

Thus, in acidic condition, five DPs, i.e. OLO1, OLO2, OLO3, OLO4, and OLO5, were observed. OLO5 was the major DP that increased with time and the peak area of OLO was decreased. In addition to OLO3 and OLO5, two more DPs were observed in alkaline condition, i.e. OLO6 and OLO7. OLO5 and OLO6 were two major DPs; OLO5 increased with time while OLO6 had a zigzag pattern of peak area with time. All DPs of neutral condition were also found in acidic condition, while OLO3 and OLO5 were common in all three types of hydrolytic degradation. Thus, OLO has a similar pattern of degradation profiling in all hydrolytic conditions (acidic, alkaline, and neutral) (Figure 4). No degradation was found in thermal and UV light exposure, as these were performed on solid powder of OLO, and so it is possible that degradation is less likely in the solid powder. Similarly, oxidative degradation was also not observed over 10 days.

\section{Degradation pathway and impurity profiling}

Standard drug OLO: LC-MS was performed in positive mode using leucine enkephalin as standard, where OLO and its impurity (OLO-Imp) were observed at relative retention time (RRT) of 1.00 and 1.11, respectively. The ESI mass spectrum of

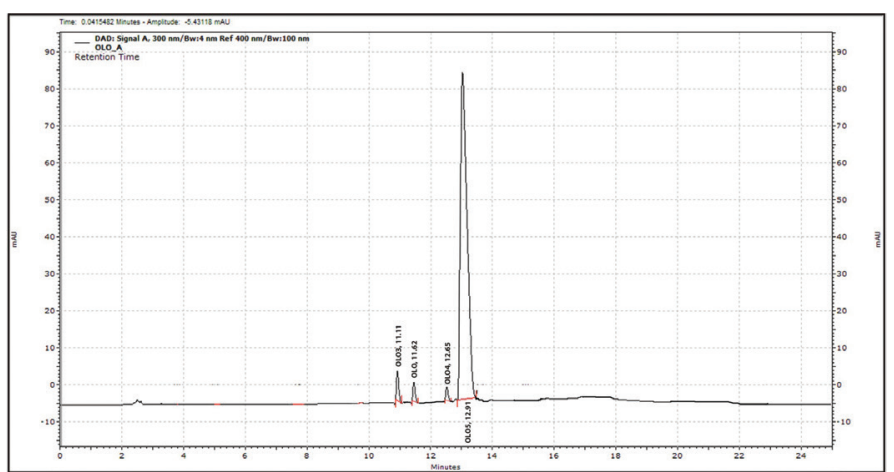

Figure 3. Representative chromatogram of OLO in neutral condition OLO: Olopatadine

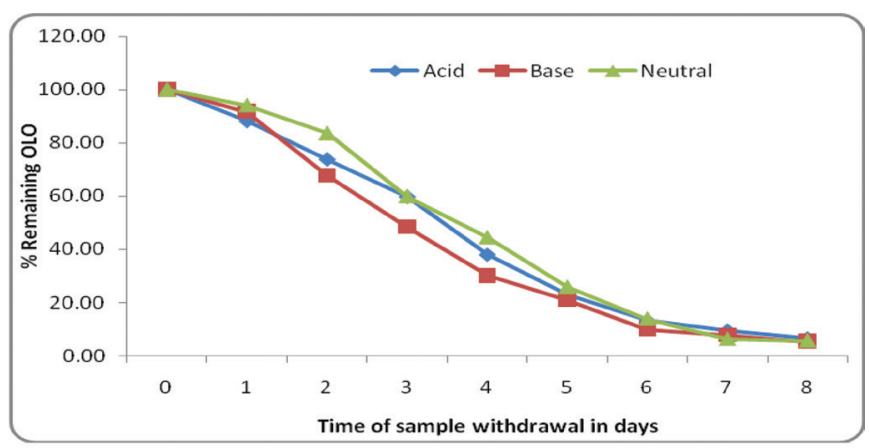

Figure 4. Degradation profiling of OLO in acidic, basic, and neutral conditions

OLO: Olopatadine
OLO showed a protonated molecular ion $[\mathrm{M}+\mathrm{H}]^{+}$and its isotopic abundance $[\mathrm{M}+2 \mathrm{H}]^{+}$at $\mathrm{m} / z 338.1671$ and 339.1663 with $\mathrm{ppm}$ errors in mass 2.08 and 4.45, respectively. It was advocated by its further fragmentation pattern into its daughter products as: $337.1678 \rightarrow 292.1099 \rightarrow 221.0961 \rightarrow 247.1117 \rightarrow 165.0546$ (Table 1, Figure 5).

An impurity, OLO-Imp (OLO5), was observed in the ESI spectrum, and its protonated molecular ion $[\mathrm{M}+\mathrm{H}]^{+}$was observed at $\mathrm{m} / \mathrm{z} 352.1840$ along with its isotopic abundance (Figure 6). Its structure was an analogue of OLO and proposed as 11-[(3-dimethylamino)-propylidene]-6,11-dihydro-dibenz[b,e] oxepin-2-propanoic acid (Figure 6). It was also used as internal standard for the metabolite study. ${ }^{10}$

Acidic degradation: In addition to OLO, sodium salt of OLO (OLO3) and OLO5 (OLO-Imp) were observed in the MS spectrum of the acidic condition sample at RRT of 0.96 and 1.11. OLO3 was observed in all three degradation conditions. Its protonated molecular ion $[\mathrm{M}+\mathrm{H}]^{+}$was observed at $\mathrm{m} / z$ 360.1502, which showed its carboxylic acid analogue at $\mathrm{m} / \mathrm{z} 338.1684$. The MSMS fragmentation pattern into its daughter products indicated the purposed structure as: $359.1497 \rightarrow 337.1678 \rightarrow 279.1623$

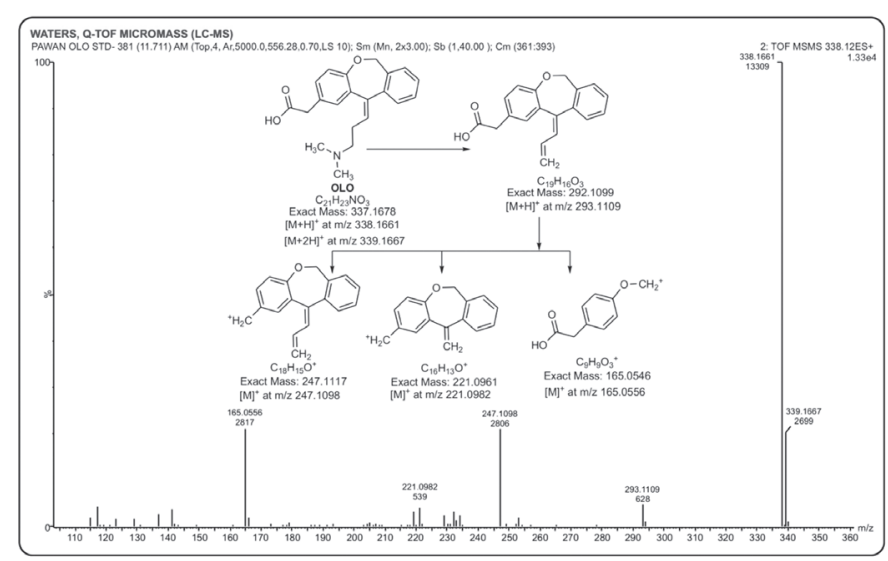

Figure 5. Chromatogram of OLO by TOF MS-MS spectrum and proposed fragmentation pattern of OLO

OLO: Olopatadine, MS: Mass spectrometry

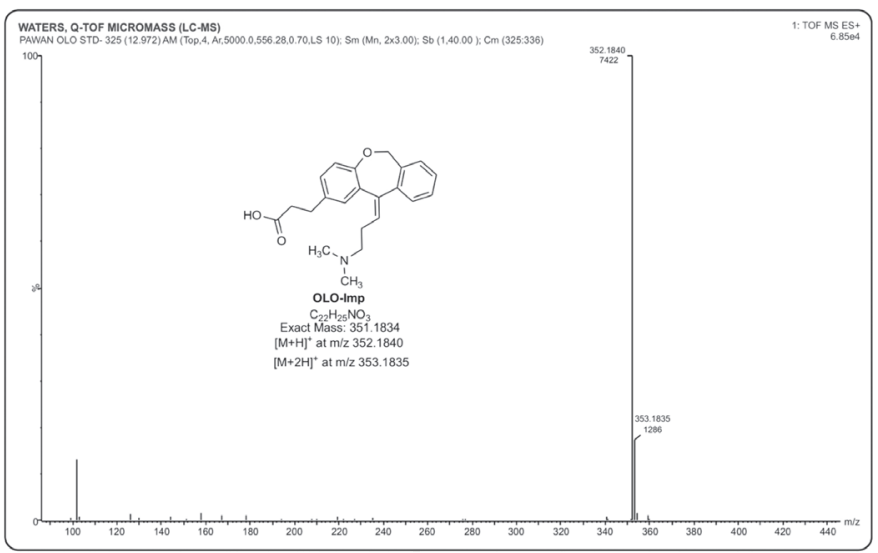

Figure 6. Chromatogram of OLO-Imp by TOF MS-ES+ and proposed structure of OLO-Imp

OLO: Olopatadine, MS: Mass spectrometry, ES: Electrospray 


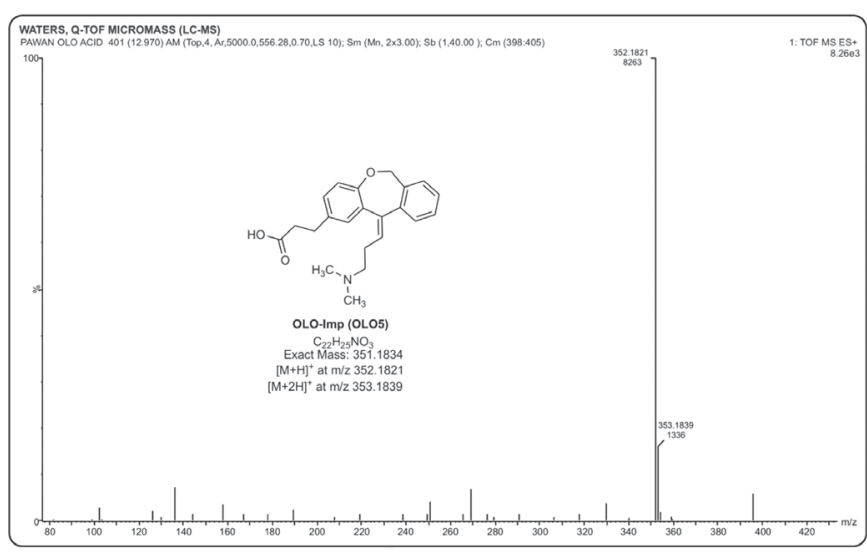

Figure 7. Chromatogram of OLO5 by TOF MS-ES+ spectrum and proposed structure of OLO5 in acidic condition

OLO: Olopatadine, MS: Mass spectrometry, ES: Electrospray

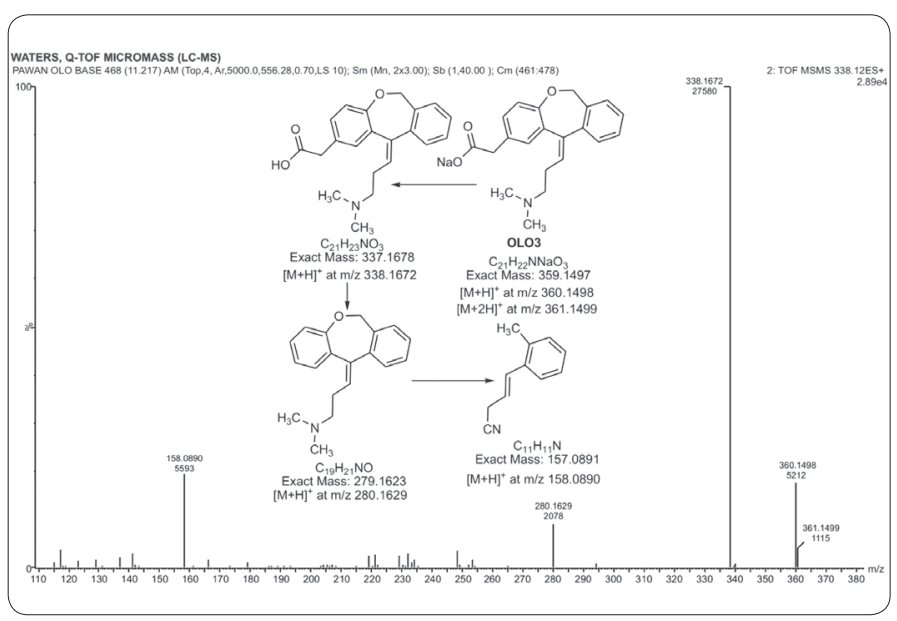

Figure 8. Chromatogram of degraded OLO in alkaline condition by TOF MSMS spectrum and proposed fragmentation pattern of OLO3

OLO: Olopatadine, MS: Mass spectrometry, ES: Electrospray

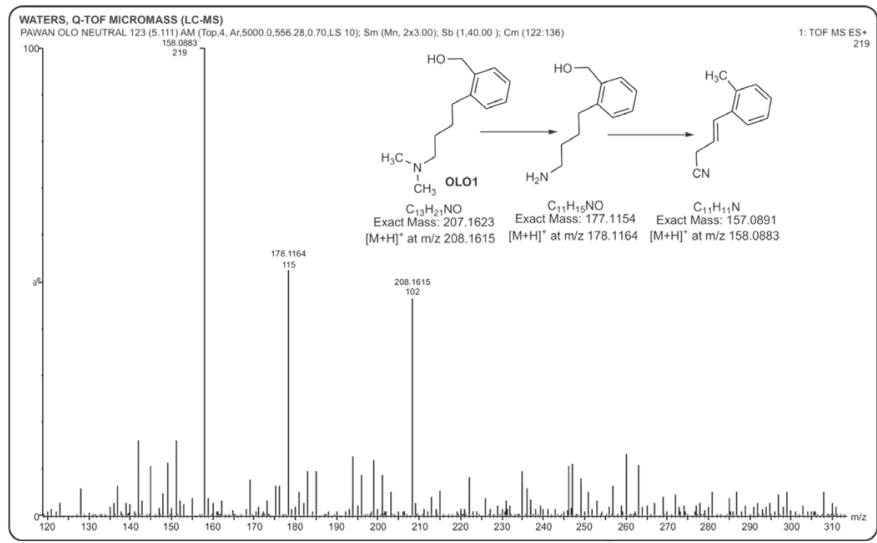

Figure 9. Chromatogram of degraded OLO in neutral condition by TOF MSES+ spectrum and proposed fragmentation pattern of OLO1

OLO: Olopatadine, MS: Mass spectrometry, ES: Electrospray

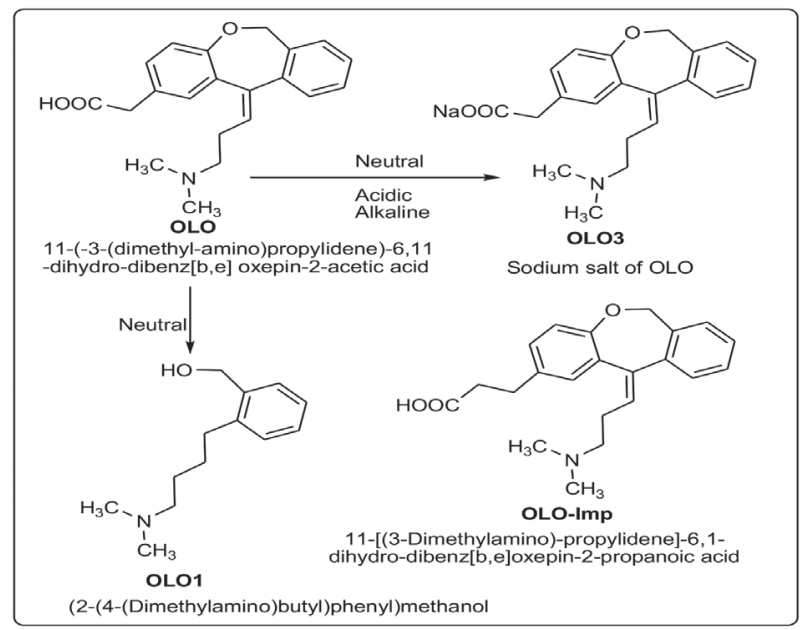

Figure 10. Proposed structure of OLO-Imp and proposed degradation pathway of OLO in acidic, alkaline, and neutral conditions

OLO: Olopatadine

\section{Table 1. Observed $\mathrm{m} / \mathrm{z}$ values for $[\mathrm{M}+\mathrm{H}]^{+}$ions and major fragments of OLO and its impurity}

\begin{tabular}{|c|c|c|c|c|c|c|c|}
\hline Analyte code & RRT in LC MS & $\begin{array}{l}\text { MS-ES or } \\
\text { MS-MS }\end{array}$ & $\mathrm{m} / \mathrm{z}$ value & Measured mass & $\begin{array}{l}\text { Best possible } \\
\text { molecular formulae }\end{array}$ & Exact mass & ppm error \\
\hline \multirow[t]{7}{*}{ OLO } & 1.00 & MS-ES & 338.1671 & 337.1671 & $\mathrm{C} 21 \mathrm{H} 23 \mathrm{NO} 3$ & 337.1678 & 2.08 \\
\hline & & & 340.1701 & 337.1701 & $\mathrm{C} 21 \mathrm{H} 23 \mathrm{NO} 3$ & 337.1678 & -6.82 \\
\hline & 1.00 & MS-MS & 338.1661 & 337.1661 & C21H23NO3 & 337.1678 & 5.04 \\
\hline & & & 293.1109 & 292.1109 & $\mathrm{C} 19 \mathrm{H} 1603$ & 292.1099 & -3.42 \\
\hline & & & 247.1098 & 247.1098 & $\mathrm{C} 18 \mathrm{H} 150+$ & 247.1117 & 7.69 \\
\hline & & & 221.0982 & 221.0982 & $\mathrm{C} 16 \mathrm{H} 130+$ & 221.0961 & -9.50 \\
\hline & & & 165.0556 & 165.0556 & $\mathrm{C9H9O3+}$ & 165.0546 & -6.06 \\
\hline
\end{tabular}

RRT: Relative retention time, OLO: Olopatadine, LC: Liquid chromatography, MS: Mass spectrometry, ES: Electrospray 
$\rightarrow 157.0891$ (Table 2). OLO was also characterized in acidic degradation at RRT of 1.00. MS-ES ${ }^{+}$scanning revealed the protonated molecular ion $[\mathrm{M}+\mathrm{H}]^{+}$of $\mathrm{OLO}$ at $\mathrm{m} / \mathrm{z} 338.1676$ with isotopic abundance. MS-MS of OLO in acidic condition showed the fragmentation pattern in the mass spectrum as: 337.1678 $\rightarrow 292.1099 \rightarrow 247.1117 ; 165.0546$ (Table 2). The protonated molecular ion $[\mathrm{M}+\mathrm{H}]^{+}$of OLO5 was observed at $\mathrm{m} / \mathrm{z} 352.1821$ with isotopic abundance at 353.1839 (Figure 7). The ppm error in mass was less than five units (Table 2).

Alkaline degradation: The MS spectrum of the alkaline sample of OLO was similar to the MS spectrum of acidic condition. The degradation pathway and fragmentation pattern of OLO and its DPs were similar to those in acidic condition (Figure 8). Only ppm error in mass varied from acidic condition (Table 3 ).

Neutral degradation: In neutral condition, the tricyclic ring underwent cleavage and OLO1 was formed (RRT=0.44). OLO3 was also formed in a similar pattern to acidic and alkaline conditions (RRT=0.96). OLO5 (OLO-Imp) was also observed in the MS spectrum similar to all other conditions. Only one additional DP (OLO1) was observed in neutral condition, whose protonated molecular ion $[\mathrm{M}+\mathrm{H}]^{+}$was found at $\mathrm{m} / z 208.1615$ and identified as (2-(4-(dimethylamino)butyl) phenyl)methanol (Figure 9). The proposed structure was further advocated by its degradation pattern (207.1623 $\rightarrow 177.1154 \rightarrow 157.0891$ ) (Table 4). OLO3, OLO, and OLO5 were also characterized in neutral condition similar to above both acidic and alkaline conditions. The ppm error in mass is different from the above conditions but most of the error is below 5 units (Table 4).
Thus, OLO and its impurity (OLO-Imp) were observed at RRT of 1.00 and 1.11, respectively, in the LC-MS study. OLO-Imp was recognized as an analogue structure of OLO and proposed as 11-[(3-dimethylamino)- propylidene]-6, 11-dihydro-dibenz[b,e] oxepin-2-propanoic acid (Figure 10). In addition to OLO, sodium salt of OLO (OLO3) and OLO5 (OLO-Imp) were observed in the MS spectrum of acidic and alkaline conditions samples at RRT of 0.96 and 1.11. OLO3 was observed in all three degradation conditions and identified as sodium salt of OLO (OLO is a carboxylic acid derivative). Additionally, OLO1 (RRT=0.44) was identified as (2-(4-(dimethylamino)butyl) phenyl)methanol, which may be formed by cleavage of the tricyclic ring in neutral condition. OLO is an acetic acid derivative along with oxepin ring and tertiary nitrogen, which is quite a stable form of drug. There is no vulnerable functional group liable to convert or break down into DPs under stressed or forced degradation conditions. Thus, OLO forms relatively slow and fewer DPs.

\section{CONCLUSION}

OLO has a similar pattern of degradation profiling in all hydrolytic conditions (acidic, alkaline, and neutral), while no degradation was found in thermal, UV light, and oxidative conditions over 10 days. OLO-Imp was recognized as an analogue structure of OLO and proposed as 11-[(3-dimethylamino)-propylidene]6,11-dihydro-dibenz[b,e]oxepin-2-propanoic acid. OLO3 was observed in all three degradation conditions and identified as sodium salt of OLO (OLO is a carboxylic acid derivative). Additionally, OLO1 was identified as (2-(4-(dimethylamino)

Table 2. Observed $\mathrm{m} / \mathrm{z}$ values for the $[\mathrm{M}+\mathrm{H}]^{+}$ions and major fragments of OLO and its degradation products in acidic condition

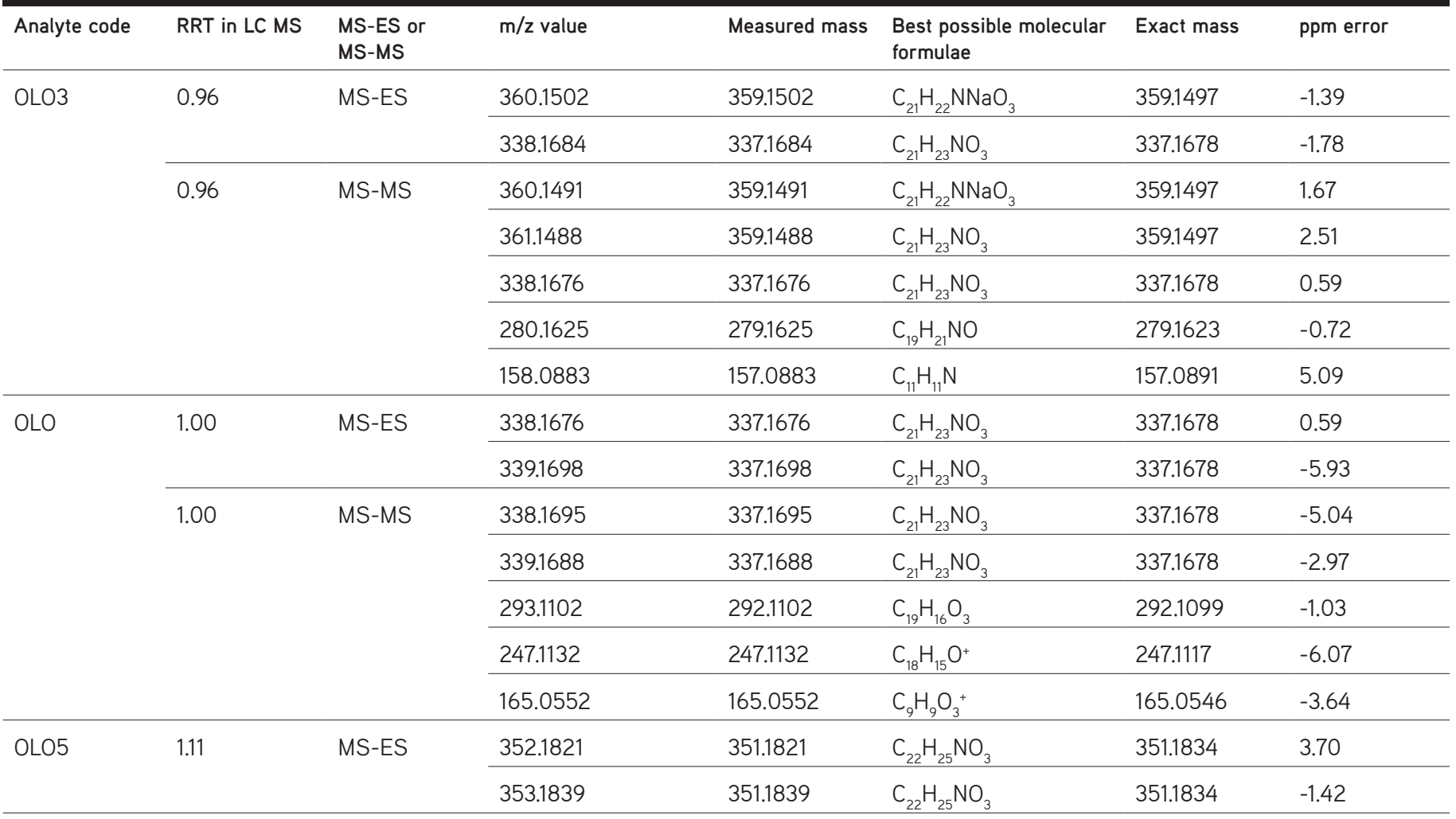

RRT: Relative retention time, OLO: Olopatadine, LC: Liquid chromatography, MS: Mass spectrometry, ES: Electrospray 
Table 3. Observed $\mathrm{m} / \mathrm{z}$ values for the $[\mathrm{M}+\mathrm{H}]^{+}$ions and major fragments of $\mathrm{OLO}$ and its degradation products in alkaline condition

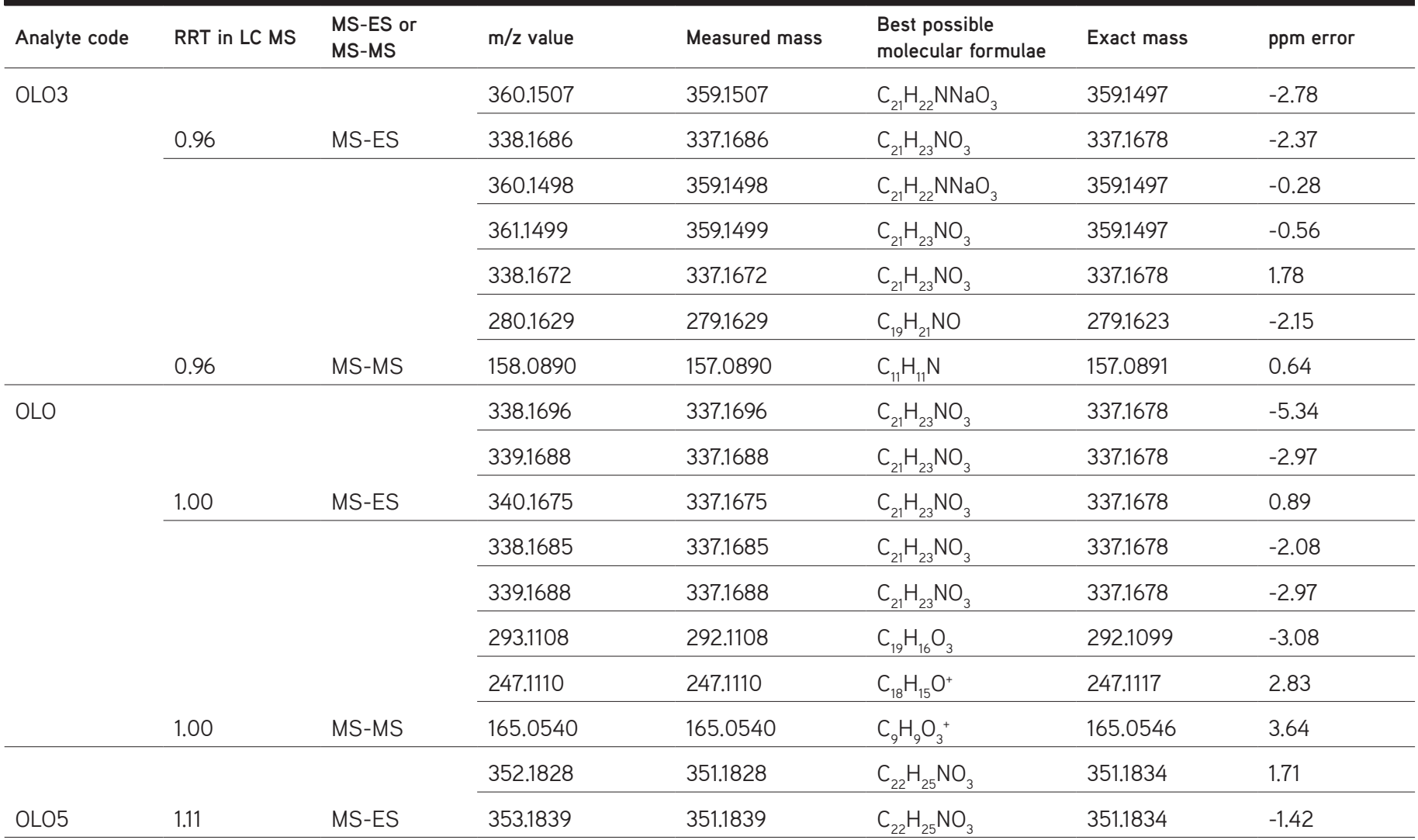

RRT: Relative retention time, OLO: Olopatadine, LC: Liquid chromatography, MS: Mass spectrometry, ES: Electrospray

Table 4. Observed $\mathrm{m} / \mathrm{z}$ values for the $[\mathrm{M}+\mathrm{H}]^{+}$ions and major fragments of OLO and its degradation products in neutral condition

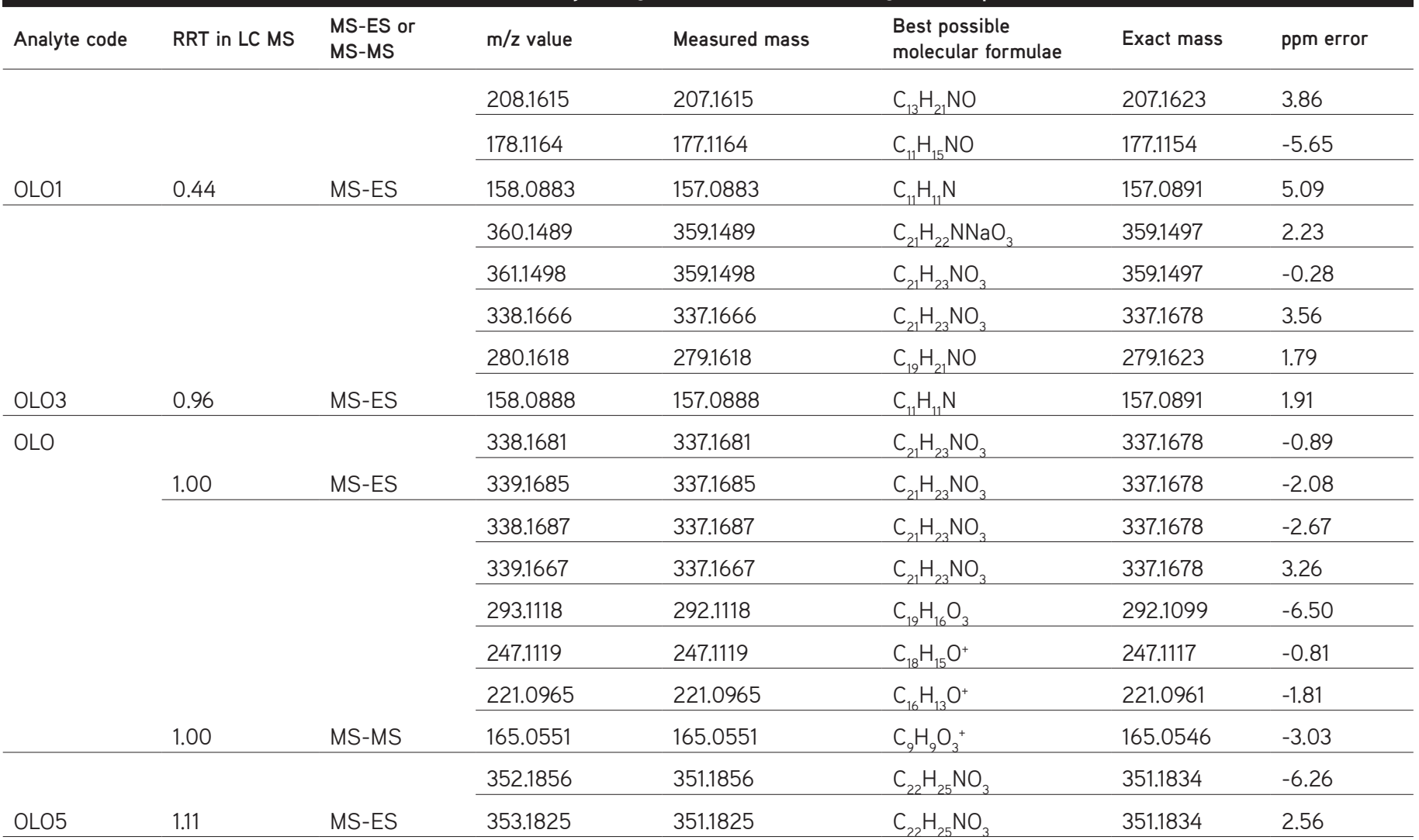

RRT: Relative retention time, OLO: Olopatadine, LC: Liquid chromatography, MS: Mass spectrometry, ES: Electrospray 
butyl)phenyl)methanol, which may be formed by cleavage of the tricyclic ring in neutral condition.

\section{ACKNOWLEDGEMENTS}

One of the authors, Pawan Kumar Basniwal, is earnestly indebted to the Science and Engineering Research Board, DST, New Delhi, for the financial support for this research work under Fast Track Scheme for Young Scientists [SR/FT/LS$187 / 2008(G)]$.

Conflicts of interest: No conflict of interest was declared by the authors.

\section{REFERENCES}

1. Jain D, Basniwal PK. Forced degradation and impurity profiling: Recent trends in analytical perspectives. J Pharm Biomed Anal. 2013;86:11-35.

2. Singh S, Handa T, Narayanam M, Sahu A, Junwal M, Shah RP. A critical review on the use of modern sophisticated hyphenated tools in the characterization of impurities and degradation products. J Pharm Biomed Anal. 2012;69:148-173.

3. Jain D, Basniwal PK. Intrinsic Stability Study of Armodafinil Hydrochloride by Forced Degradation and Impurity Profiling. Pharm Anal Acta. 2016;7:466.

4. Ohshima E, Ohtaki S, Sato $H$, Kumazawa T, Obase $H$, Ishii A, Ishii $\mathrm{H}$, Ohmori K, Hirayama N. Synthesis and antiallergic activity of 11-(aminoalkylidene)-6,11-dihydrodibenz [b,e] oxepin derivatives. J Med Chem. 1992;35:2074-2084.

5. Scoper SV, Berdy GJ, Lichtenstein SJ, Rubin JM, Bloomenstein M, Prouty RE, Vogelson CT, Edwards MR, Waycaster C, Pasquine T, Gross RD, Robertson SM. Perception and quality of life associated with the use of olopatadine $0.2 \%$ (Pataday) in patients with active allergic conjunctivitis. Adv Ther. 2007;24:1221-1232.

6. Kajita J, Inano K, Fuse E, Kuwabara T, Kobayashi H. Effects of olopatadine, a new antiallergic agent, on human liver microsomal cytochrome p450 activities. Drug Metab Dispos. 2002;30:1504-1511.

7. McGill JI. A review of the use of olopatadine in allergic conjunctivitis. Int Ophthalmol. 2004;25:171-179.

8. Takahashi H, Zhang Y, Morita E. Evaluation of the antihistamine effects of olopatadine, cetirizine and fexofenadine during a $24 \mathrm{~h}$ period: $\mathrm{A}$ double-blind, randomized, crossover, placebo-controlled comparison in skin responses induced by histamine iontophoresis. Arch Dermatol Res. 2008;300:291-295.
9. Ohishi T, Magara H, Yasuzawa T, Kabayashi H, Yamaguchi K, Kobayashi S. Disposition of KW-4679 (4): metabolism of KW-4679 in rats and dogs. Xenobiol Metab Dispos. 1995;10:689-706.

10. Tsunoo M, Momomura S, Masuo M, lizuka H. Phase 1 clinical study on KW-4679, an antiallergic drug: Safety and pharmacokinetics in the single and repeated administration study to healthy subjects. Kiso To Rinsho. 1995;29:4129-4147.

11. Zhu P, Wen Y, Fan XP, Zhou ZL, Fan RX, Chen JM, Huang KL, Zhu XL, Chen $Y F$, Zhuang J. A rapid and sensitive liquid chromatography-tandem mass spectrometry method for determination of olopatadine concentration in human plasma. J Anal Toxicol. 2011;35:113-118.

12. Fujimaki K, Lee XP, Kumazawa T, Sato J, Sato K. Determination of some antiallergic drugs in human plasma by direct-injection high-performance liquid chromatography-tandem mass spectrometry. Forensic Toxicol. 2006;24:8-16.

13. Fujita $\mathrm{K}$, Magara $H$, Kobayashi $H$. Determination of olopatadine, a new antiallergic agent, and its metabolites in human plasma by highperformance liquid chromatography with electrospray ionization tandem mass spectrometry. J Chromatogr B Biomed Sci Appl. 1999;731:345-352.

14. Güray T, Turan T, Tunçel M, Uysal UD. A validated capillary electrophoretic method for the determination of olopatadine and its application to a pharmaceutical preparation of eye drops. J AOAC Int. 2017;100:206-211.

15. Varghese SJ, Kumar AM, Ravi TK. Stability-indicating highperformance column liquid chromatography and high-performance thin-layer chromatography methods for the determination of olopatadine hydrochloride in tablet dosage form. J AOAC Int. 2011;94:1815-1820.

16. ICH "Stability Testing of New Drug Substance and Products", International Conference on Harmonization of Technical Requirement for Registration of Pharmaceutical for Human Use, Geneva, 2000.

17. ICH "Text on Validation of Analytical Procedures"; International Conference on Harmonization of Technical Requirements for Registration of Pharmaceutical for Human Use, Geneva, 2000.

18. ICH "Validation of Analytical Procedure: Methodology"; International Conference on Harmonization of Technical Requirements for Registration of Pharmaceutical for Human Use, Geneva, 2000.

19. Crowther JB. Validation of pharmaceutical test methods. In: Ahuja S, Scypinski S, eds. Handbook of Modern Pharmaceutical Analysis. London; Academic Press;2001:415-444.

20. Basniwal PK, Jain D. ICH guideline practice: application of novel RPHPLC-DAD method for determination of olopatadine hydrochloride in pharmaceutical products. J Analyt Sci Tech. 2013;4:12. 